\title{
Effect of autoclaving on the nutritional quality of hard-to-cook common beans (Phaseolus vulgaris)
}

\author{
Karla A Batista ${ }^{1}$, Wendell J Pereira ${ }^{2}$, Bruna R Moreira ${ }^{2}$, Cassio NS Silva ${ }^{2}$, \\ Kátia F Fernandes ${ }^{2}$
} ${ }^{1}$ Federal Institute of Education, Science and Education, Campus Goiânia Oeste, Goiás, Brazil.
${ }^{2}$ Polymer Chemistry Laboratory, Department of Biochemistry and Molecular Biology, Institute of Biological Sciences, ICB II, Federal
University of Goiás, Brazil

\begin{abstract}
A central composite rotatable design (CCRD) coupled to response surface methodology (RSM) was used to investigate the effect of autoclaving conditions on the antinutritional factors, functional properties, digestibility and hardness of hard-do-cook common beans. Results indicated that autoclaving conditions did not change the functional properties (water solubility, water absorption index and oil absorption capacity) of the autoclaved hard-to-cook beans. Nevertheless, the autoclaving process was able to reduce the content of trypsin (59.8\%) and $\alpha$-amylase (42.2\%) inhibitors as well as the amount of resistant starch (45.9\%), which improves the nutrient bioavailability. In addition, compared to unprocessed hard-to-cook beans, the autoclaved seed presented higher protein and starch digestibility and lower hardness, enhancing the nutritional and textural quality of the seeds. These results evidenced that autoclaving may be an interesting alternative to enable the use of hard-to-cook beans as whole grain or component in food preparations.
\end{abstract}

Keywords - autoclaving, functional properties, hardness, digestibility, response surface methodology.

\section{INTRODUCTION}

The common bean (Phaseolus vulgaris) is an important and inexpensive source of proteins, carbohydrate, dietary fibers, mineral and vitamins for millions of people both in developed and developing countries (Shiga, Lajolo, \& Filisetti, 2004; Toledo, Rocha, Silva, \& Brazaca, 2013). However, beans contain antinutritional factors that limit their protein and carbohydrate utilization.

Moreover, the storage of beans under the adverse conditions of high temperature and moisture renders them susceptible to the hardening phenomenon. This phenomenon is characterized by extended cooking time and losses in their nutritional and textural quality, which reduces consumer acceptability and the commercial value of beans (Ruiz-Ruiz, Martinez-Ayala, Drago, \& González, 2008).

In this sense, the inactivation and/or removal of antinutritional components as well as changes in the textural quality are essential to improving the nutritional and organoleptic acceptability of hardened beans and turn help to effectively utilize the potential of these beans in human nutrition.

Recently, alternatives technologies have been proposed to enable the use of the hard-to-cook beans (Batista, Prudencio, \& Fernandes, 2010a, 2010b, 2011; Lopes, Batista, Fernandes, \& Santiago, 2012). Among the alternative technologies, the autoclaving process is a heat treatment that improves the nutritional quality of food legumes due to reduction in the antinutritional factors and increase in the bioavailability of proteins and carbohydrates (Shimelis \& Rakshit, 2007).

However, there is scare information in the literature about the improvement in the nutritional quality of hardto-cook beans as a result of autoclaving under varied conditions. In fact, the effect of the autoclaving is dependent of the parameters used in the process, such as pressure, heating temperature and autoclaving time as well as of the intrinsic properties of the material submitted to this treatment.

Therefore, the present work was undertaken to study the effect of varied autoclaving conditions on the functional properties, antinutritional factors, protein and starch digestibility and texture profile on the hard-to-cook common beans.the introduction of the paper should explain the nature of the problem, previous work, purpose, and the contribution of the paper. The contents of each section may be provided to understand easily about the paper.

\section{MATERIAL AND METHODS}

2.1 Materials

The seeds of common bean (Phaseolus vulgaris, c.v. BRS pontal), were provided by EMBRAPA Arroz e Feijão (Goiás, Brazil). The seeds were cleaned and stored in 
polyethylene containers at $4{ }^{\circ} \mathrm{C}$ until use. The hardening was carried out incubating the seeds in an oven at $40{ }^{\circ} \mathrm{C}$ and $75 \%$ of moisture for 120 days (Ribeiro, PrudencioRibeiro, \& Miyagui, 2005). All the chemical used were analytical grade.

\subsection{Experimental design}

The effects of autoclaving parameters in the antinutritional factors, in vitro digestibility, functional and texture properties were analyzed using a central composite rotatable design (CCRD) coupled to response surface methodology (RSM). The factors and levels assessed were the binomial pressure/temperature $\left(0.5 \mathrm{Kgf} \mathrm{cm}^{-2} / 111{ }^{\circ} \mathrm{C}\right.$,

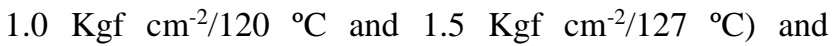
autoclaving time (15, 20 and $30 \mathrm{~min})$ (Table 1). Samples were placed into glass flasks partially capped to allow entrance of water vapor. After autoclaving the seeds were dried out at room temperature and stored in plastic bags at $4{ }^{\circ} \mathrm{C}$ until their use.

Table 1: Effect of autoclaving in the activity of trypsin and $\alpha$-amylase inhibitors.

\begin{tabular}{|c|c|c|c|c|}
\hline Run & $\begin{array}{c}\text { Pressure/Temperature } \\
\left(\mathrm{X}_{1}\right)\end{array}$ & $\begin{array}{l}\text { Time } \\
\left(\mathrm{X}_{2}\right)\end{array}$ & $\begin{array}{c}\text { Trypsin inhibitors } \\
\left(\mathrm{UI} \mathrm{g} \mathrm{g}^{-1}\right)\end{array}$ & $\begin{array}{c}\alpha \text {-amylase inhibitors } \\
\left(\mathrm{UI} \mathrm{g}^{-1}\right)\end{array}$ \\
\hline$\overline{1}$ & $0.5 / 111$ & 15 & $1025.23^{b}$ & $5809.05^{\mathrm{a}}$ \\
\hline 2 & $0.5 / 111$ & 45 & $977.77^{\mathrm{c}, \mathrm{d}}$ & $5534.83^{\mathrm{a}}$ \\
\hline 3 & $1.5 / 127$ & 15 & $770.75^{\mathrm{f}}$ & $4337.99^{\mathrm{b}, \mathrm{c}, \mathrm{d}}$ \\
\hline 4 & $1.5 / 127$ & 45 & $790.43^{\mathrm{f}}$ & $4002.07^{\mathrm{d}}$ \\
\hline 5 & $0.5 / 111$ & 30 & $996.10^{\mathrm{b}, \mathrm{c}}$ & $5295.93^{\mathrm{a}, \mathrm{b}, \mathrm{c}}$ \\
\hline 6 & $1.5 / 127$ & 30 & $965.15^{\mathrm{d}}$ & $3766.94^{\mathrm{d}}$ \\
\hline 7 & $1.0 / 120$ & 15 & $976.56^{\mathrm{c}, \mathrm{d}}$ & $4211.70^{\mathrm{c}, \mathrm{d}}$ \\
\hline 8 & $1.0 / 120$ & 45 & $870.70^{\mathrm{e}}$ & $5280.42^{\mathrm{a}, \mathrm{b}, \mathrm{c}}$ \\
\hline 9 & $1.0 / 120$ & 30 & $899.42^{\mathrm{e}}$ & $5484.11^{\mathrm{a}}$ \\
\hline 10 & $1.0 / 120$ & 30 & $894.42^{\mathrm{e}}$ & $5481.11^{\mathrm{a}}$ \\
\hline \multicolumn{3}{|c|}{ Unprocessed hardened beans } & $1918.64^{\mathrm{a}}$ & $6512.83^{a}$ \\
\hline
\end{tabular}

Results are the mean of three determinations. Within columns, means with same superscript are not significantly different $(\mathrm{P}>0.05)$.

\subsection{Texture analysis}

The texture of the samples was evaluated through a compression test performed using a Lloyd TA1 material testing system (Lloyd Instruments Ltd, Hants, UK). Samples of unprocessed and autoclaved hard-to-cook beans were cooked at $110^{\circ} \mathrm{C}$ for $15 \mathrm{~min}$ and the texture tested using two flat-faced $50 \mathrm{~mm}$ diameter metal discs with a crosshead speed of $2 \mathrm{~mm} \mathrm{seg}^{-1}$ and a compression ratio of 0.9 (i.e., a seed with an average height of $10 \mathrm{~mm}$ was compressed to $9 \mathrm{~mm}$ ). The bean seeds were tested individually and the analysis employed was the return-tostart (RTS) method, measuring force under compression with a $500 \mathrm{~N}$ load cell. For each treatment at least 50 seeds were tested.

\subsection{Antinutritional factors}

The unprocessed and autoclaved seeds were ground to pass through a $0.5-\mathrm{mm}$ mesh and the produced flour used to evaluate the content of antinutritional factors. The trypsin inhibitor activity was determined according to Kakade et al. (1974), using casein as the substrate for trypsin. One trypsin unit was defined as the increase of 0.1 absorbance unit at $280 \mathrm{~nm}$. The unit of inhibition (UI) was defined as the relationship between the units observed in the maximum activity and the activity of the samples containing the inhibitors.

The activity of $\alpha$-amylase inhibitor was determined according to methodology described by Deshpande et al. (1982), using starch as the substrate for the enzyme. One unit of $\alpha$-amylase was defined to be the amount of enzyme that would produce $1.0 \mu \mathrm{mol}$ of reducing per min of reaction. One unit of inhibition (UI) was defined as the relationship between the units observed in the maximum activity and the activity of the samples containing the inhibitors.

\subsection{Functional properties}

The water absorption index (WAI) and the oil absorption capacity (OAC) were determined according to methodology described by Okezie and Bello (1988). One gram of unprocessed or autoclaved hard-to-cook bean flour was mixed in $50 \mathrm{~mL}$ of distilled water or soybean oil and centrifuged at $3000 \mathrm{~g}$ for $20 \mathrm{~min}$. The WAI and OAC were calculated according to the equation (1):

$$
\text { WAI or OAC }\left(\mathrm{g} \mathrm{g}^{-1}\right)=\frac{\text { weight of wet sediment }(g)}{\text { weight of initial sample }(g)}
$$

The water solubility (WS) analysis was carried out according to the method described by Okezie and Bello 
(1988). The supernatant obtained in the WAI assay was dried to constant weight in an oven at $105{ }^{\circ} \mathrm{C}$. The solubility was calculated using the equation (2):

$$
\text { WS }\left(\mathrm{g} \mathrm{g}^{-1}\right)=\frac{\text { weight of dried supernatant }(g)}{\text { weight of initial sample }(g)}
$$

2.6. Starch quantification an in vitro digestibility test The content of total starch (TS) was determined according to methodology described by Goni et al. (1997), with slight modifications. $50 \mathrm{mg}$ of unprocessed or autoclaved hard-to-cook bean flour were dispersed in $5 \mathrm{~mL}$ of $2 \mathrm{~mol}$ $\mathrm{L}^{-1} \mathrm{KOH}$ solution and incubated under shaking for $30 \mathrm{~min}$ at room temperature. After that, $\mathrm{pH}$ of the mixture was adjusted to 5.5 with $0.5 \mathrm{~mol} \mathrm{~L}^{-1} \mathrm{HCl}$ solution and hydrolyzed using amyloglucosidase (Novozyme) for 60 min at $50{ }^{\circ} \mathrm{C}$. Glucose was quantified using the glucose oxidase/peroxidase reagent (DOLES) and the total starch was calculated as glucose x 0.9, after correction for the free glucose content.

In vitro starch digestibility was carried out as described by Batista et al. (2010a), with slight modifications. Samples were sequentially digested with $\alpha$-amylase and amyloglucosidase and the content of released glucose was determined using the glucose oxidase/peroxidase reagent (DOLES). The extension of starch hydrolysis was calculated using equation (3):

$$
\text { Starch digestibility }(\%)=\frac{\text { (content of glucose relassed affer digestion) }) \times 0.9}{\text { total starch of sample }} \times 100
$$

The resistant starch was calculated by the difference between total and digestible starch, according to the equation (4):

$$
\text { Resistant starch ( } \mathrm{g} \mathrm{g}^{-1} \text { total starch) }=\text { TS (total starch) - DS (digestible starch) }
$$

The surface topography of the starch from untreated and autoclaved bean flours was observed by scanning electron microscopy (SEM). A dry, finely ground sample was placed on double-sided Scotch tape, mounted on an aluminum specimen holder, and coated with a thin film of gold under vacuum. Samples were observed under a Jeol scanning electron microscope (JSM 6610, Jeol, Japan).

\subsection{In vitro protein digestibility test}

In vitro protein digestibility was determined using the multienzymatic technique described by Hsu et al. (1977). Samples were mixed with $0.1 \mathrm{~mol} \mathrm{~L}^{-1}$ sodium phosphate buffer $\mathrm{pH} 8.0$ and a multi-enzyme mixture (trypsin and pancreatine). The digestibility was determined by the digestion at $37{ }^{\circ} \mathrm{C}$, under stirring. The $\mathrm{pH}$ drop of the samples from $\mathrm{pH} 8.0$ was recorded after $10 \mathrm{~min}$ of incubation. The in vitro digestibility was calculated according to the following regression equation:

$$
\% \text { digestibility }=425.68-47.64(\mathrm{pH} \text { drop })
$$

\subsection{Statistical analysis}

The results were expressed as mean \pm standard deviation $(\mathrm{X} \pm \mathrm{SD})$. The variance analysis (ANOVA) and Tukey's test were used to define differences in mean values of the data from 3 replicates. Results from CCRD were analyzed by using the software Statistica 7.0 (Statsoft, Inc., Tulsa, USA) and the experimental results were fitted via the response surface regression procedure, using the following second-order polynomial equation:

$$
Y=\alpha_{0}+\sum_{i} \alpha_{i} X_{i}+\sum_{i i} \alpha_{i i} X_{i}^{2}+\sum_{i j} \alpha_{i j} X_{i} X_{j}
$$

Where $Y$ is the predicted response, $\alpha_{0}$ is the intercept term; $\alpha_{\mathrm{i}}$ is the linear coefficient; $\alpha_{i i}$ is the quadratic coefficient; $\alpha_{i j}$ is the interaction coefficients and $X_{i}$ and $X_{j}$ are the levels of the independent variables. The model was simplified by dropping terms that were not statistically significant ( $>0.05)$ by ANOVA.

\section{RESULTS AND DISCUSSION}

\subsection{Antinutritional factors}

\subsubsection{Trypsin inhibitors}

Though beans are important sources of dietary protein for food nutrition, their acceptance and utilization has been limited due to the presence of antinutritional factors. The enzyme inhibitors figure among the most important antinutritional factors since they limit the hydrolysis of carbohydrates and protein, reducing the nutrient bioavailability.

Table 1 shows the effect of the autoclaving parameters in the content of enzyme inhibitors. As can be observed, the treatment by autoclaving resulted in a reduction ranging from $48.1 \%$ to $59.8 \%$ in the activity of trypsin inhibitors. Multivariate analysis showed that both pressure/temperature $\left(X_{1}\right)$ and autoclaving time $\left(X_{2}\right)$ significantly $(p<0.05)$ affected the inhibitors activity. Fig. 1a shows the graphical representation (Pareto chart) of the magnitude of each of the parameters investigated upon inhibitors activity. As shown, the linear term of pressure 
and quadratic and linear terms of autoclaving time negatively affected the trypsin inhibitory activity.

The graphical representation of significant effects of inter-relations and interactions of the independent variables on the content of trypsin inhibitors are depicted
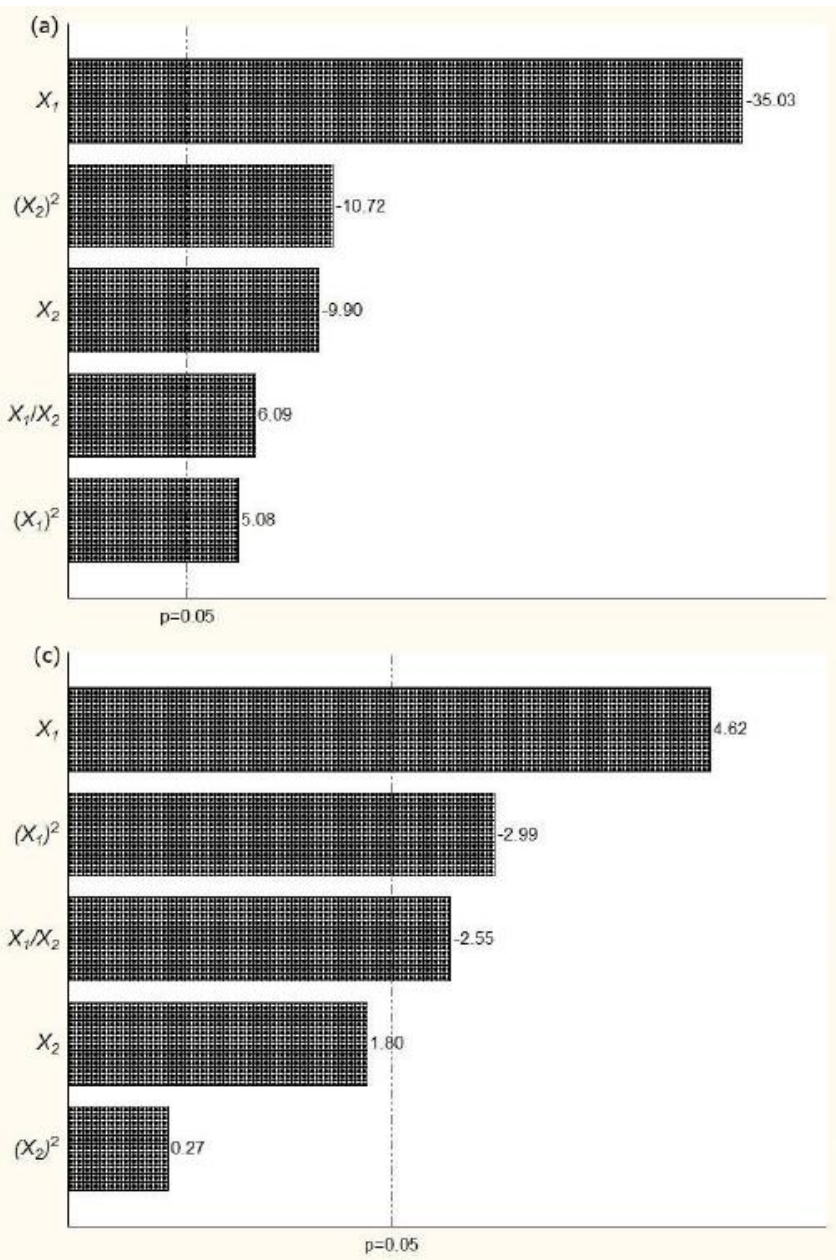

in Fig. 2a. As can be observed the increase of the pressure/temperature leads to a reduction in the trypsin inhibition, independently of the autoclaving time. The lower inhibitory activity was produced with autoclaving at $1.5 \mathrm{Kgf} \mathrm{cm}^{-2} / 127^{\circ} \mathrm{C}$ for $15 \mathrm{~min}$ (run 3) or $45 \mathrm{~min}$ (run 4).
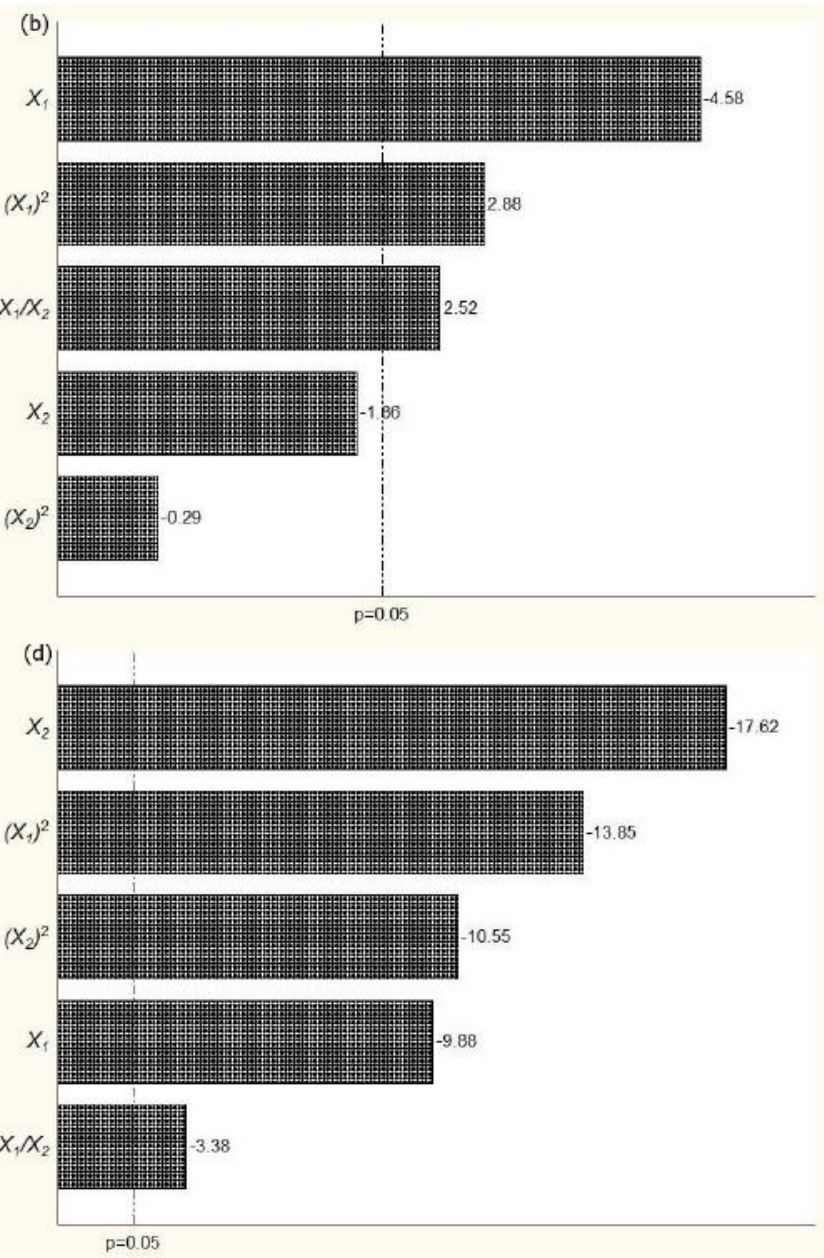

Fig.1: Pareto chart for the (a) trypsin inhibitors, (b) resistant starch, (c) starch digestibility and (d) hardness of autoclaved hardened beans.

Additionally, the regression analysis for trypsin inhibitory activity in common bean seeds showed an adequate fit of experimental values to the second-order polynomial model as a function of significant factors. The mathematical model is represented by the following equation $\left(r^{2}=0.85\right)$ :

\section{Trypsin inhibitor activity $\left(\mathrm{IU} \mathrm{g}^{-1}\right)=1116.25-371.29 X_{1}+73.28 X_{1}^{2}+6.59 X_{2}-0.17 X_{2}^{2}+2.24 X_{1} X_{2}$}

Several authors reported that thermal stability of the trypsin inhibitors depends on the temperature and processing time, particles size as well as moisture content of the samples (Khattab \& Arntfield, 2009; Shimelis \& Rakshit, 2007). Furthermore, trypsin inhibitors are proteins that can be affected by pressure at the molecular level. Pressure may disrupt the protein non-covalent and covalent bonds leading to inactivation of the trypsin inhibitory activity (Guerrero-Beltrán, Estrada-Girón, Swanson, \& Barbosa-Cánovas, 2009).

In this sense, despite the high thermal stability of some trypsin inhibitors, the combination of temperature, pressure and autoclaving time was able to reduce the inhibitory activity. This reduction in the trypsin inhibitors contributes to improve the nutritional quality of the hardto-cook common beans submitted to autoclaving. 
(a)

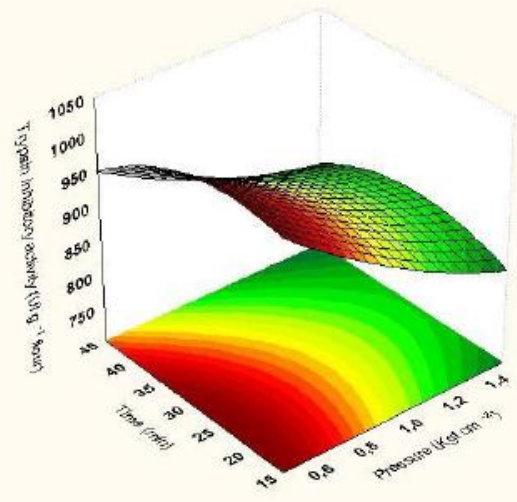

(c)

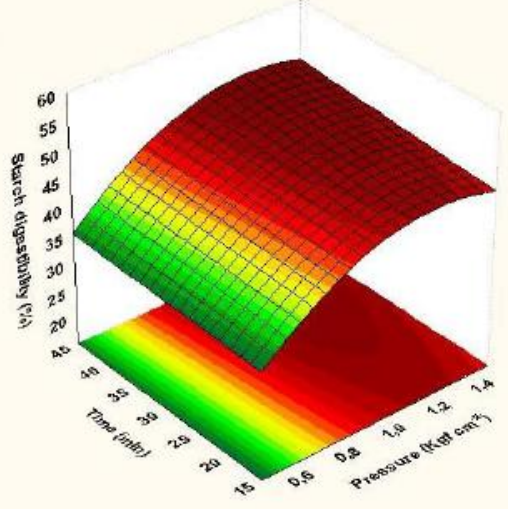

(b)

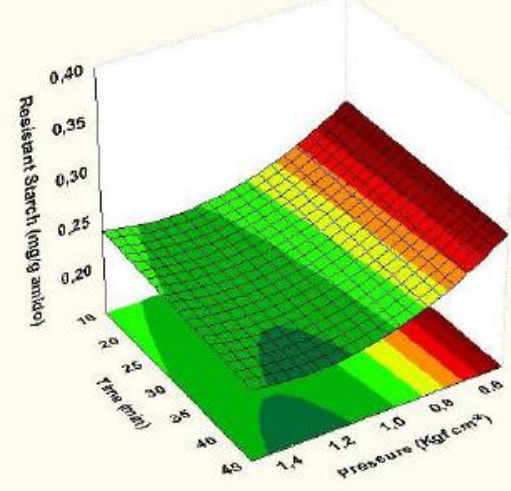

(d)

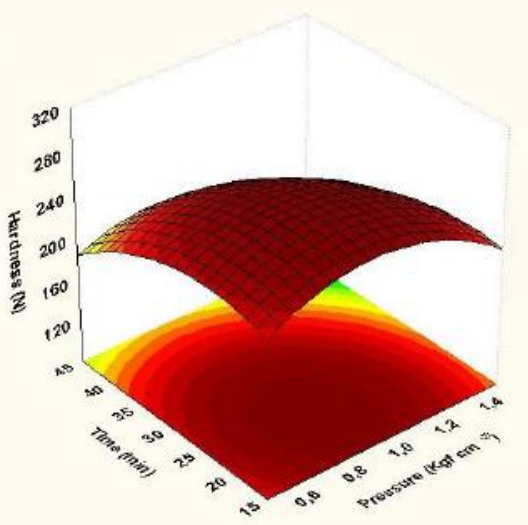

Fig.2: Response surface plot of a) trypsin inhibitors, (b) resistant starch, (c) starch digestibility and (d) hardness as a function of pressure/temperature and autoclaving time.

\subsection{2. $\alpha$-amylase Inhibitors}

The $\alpha$-amylase inhibitors are antinutritional factors responsible by inactivation of salivary and pancreatic amylases, reducing the starch digestibility and compromising the glucose bioavailability (Svensson, Fukuda, Nielsen, \& Bonsager, 2004).

The effects of autoclaving on the $\alpha$-amylase inhibitors activity are shown in the Table 1 . As can be seen, the treatment was not able to totally eliminate the $\alpha$-amylase inhibitors in the common bean seeds. The maximum reduction of $\alpha$-amylase inhibitors was obtained by autoclaving hard-to-cook beans at $1.5 \mathrm{Kgf} \mathrm{cm}^{-2} / 127{ }^{\circ} \mathrm{C}$ for $30 \mathrm{~min}$ or $45 \mathrm{~min}$. Results of the multivariate analysis showed that only the linear term of pressure/temperature $\left(X_{I}\right)$ affected the activity of the $\alpha$-amylase inhibitors in the common bean seeds. The correlation analysis showed that pressure had a negative effect $(r=-0.72)$ in the activity of amylase inhibitors. This negative correlation indicates that as the higher the pressure, the lower the activity of the $\alpha$ amylase inhibitors.

\subsection{Functional Properties}

The functional properties are closely related to the interactions between molecules constituting the food, which are affected by the inherent composition, structure and physicochemical properties.

Water absorption index (WAI) determines the absorption and retention of water as a function of food composition. Changes in the molecules properties after treatment, especially regarding to protein denaturation and starch fragmentation, may alter this parameter (Lopes et al., 2012).

The water solubility is other important functional property widely used as an indicator of starch degradation since increases in this index indicates an increase in the amount of soluble molecules in the material (Batista et al., 2010b; Lopes et al., 2012).

On the other hand, oil absorption is commonly associated with the presence of hydrophobic molecules such as lipids and proteins. Changes in native protein structure affect the oil absorption capacity (OAC) by 
exposing hydrophobic spots, increasing the availability of sites for lipid interaction.

The effect of autoclaving conditions on the WAI, WS and OAC of the studied bean seeds is shown in Table 2. Results evidenced that autoclaving process did not change the functional properties of the hard-to-cook beans Despite of the drastic conditions used in the autoclaving process, apparently the interaction among food components were not compromised.

Table 2: Effect of autoclaving on the functional properties of hardened common beans.

\begin{tabular}{|c|c|c|c|}
\hline Run & Water solubility (\%) & Water absorption index $\left(\mathrm{g} \mathrm{g}^{-1}\right)$ & Oil absorption index $\left(\mathrm{g} \mathrm{g}^{-1}\right)$ \\
\hline 1 & $24.03^{\mathrm{a}, \mathrm{b}}$ & $4.44^{\mathrm{a}}$ & $5.37^{\mathrm{a}}$ \\
\hline 2 & $16.35^{\mathrm{b}}$ & $4.31^{\mathrm{a}}$ & $5.44^{\mathrm{a}}$ \\
\hline 3 & $22.66^{\mathrm{a}, \mathrm{b}}$ & $4.19^{\mathrm{a}}$ & $5.46^{\mathrm{a}}$ \\
\hline 4 & $24.07^{\mathrm{a}, \mathrm{b}}$ & $5.59^{\mathrm{a}}$ & $5.37^{\mathrm{a}}$ \\
\hline 5 & $24.02^{\mathrm{a}, \mathrm{b}}$ & $4.42^{\mathrm{a}}$ & $5.12^{\mathrm{a}}$ \\
\hline 6 & $21.81^{\mathrm{a}, \mathrm{b}}$ & $4.29^{\mathrm{a}}$ & $5.28^{\mathrm{a}}$ \\
\hline 7 & $25.97^{\mathrm{a}}$ & $4.32^{\mathrm{a}}$ & $4.80^{\mathrm{a}}$ \\
\hline 8 & $19.29^{\mathrm{a}, \mathrm{b}}$ & $4.27^{\mathrm{a}}$ & $5.40^{\mathrm{a}}$ \\
\hline 9 & $22.70^{\mathrm{a}, \mathrm{b}}$ & $4.82^{\mathrm{a}}$ & $5.32^{\mathrm{a}}$ \\
\hline 10 & $22.75^{\mathrm{a}, \mathrm{b}}$ & $4.80^{\mathrm{a}}$ & $5.30^{\mathrm{a}}$ \\
\hline Unprocessed hardened beans & $22.31^{\mathrm{a}, \mathrm{b}}$ & $4.22^{\mathrm{a}}$ & $5.63^{\mathrm{a}}$ \\
\hline
\end{tabular}

Results are the mean of three determinations. Within columns, means with same superscript are not significantly different $(\mathrm{P}>0.05)$.

\subsection{Total starch and in vitro digestibility}

The total starch content varied from $42.6 \%$ to $44.9 \%$ in the unprocessed and autoclaved hard-to-cook bean flours. These results are in agreement with those reported in the literature for Phaseolus vulgaris (Rehman \& Shah, 2005) The results of resistant starch and in vitro digestibility are shown in Table 3.

Table 3: Effect of autoclaving in the content of resistant and digestible starch of the hardened beans.

\begin{tabular}{ccccc}
\hline Run & $\begin{array}{c}\text { Pressure/Temperature } \\
\left(\mathrm{X}_{1}\right)\end{array}$ & $\begin{array}{c}\text { Time } \\
\left(\mathrm{X}_{2}\right)\end{array}$ & $\begin{array}{c}\text { Resistant starch } \\
\left(\mathrm{g} \mathrm{g}^{-1} \text { total starch }\right)\end{array}$ & $\begin{array}{c}\text { Digestible starch } \\
(\%)\end{array}$ \\
\hline 1 & $0.5 / 111$ & 15 & $0.35^{\mathrm{a}}$ & $20.34^{\mathrm{f}}$ \\
2 & $0.5 / 111$ & 45 & $0.26^{\mathrm{b}}$ & $40.91^{\mathrm{e}}$ \\
3 & $1.5 / 127$ & 15 & $0.23^{\mathrm{c}, \mathrm{d}}$ & $48.42^{\mathrm{b}, \mathrm{c}}$ \\
4 & $1.5 / 127$ & 45 & $0.22^{\mathrm{d}, \mathrm{e}}$ & $51.16^{\mathrm{a}, \mathrm{b}}$ \\
5 & $0.5 / 111$ & 30 & $0.25^{\mathrm{b}, \mathrm{c}}$ & $42.92^{\mathrm{d}, \mathrm{e}}$ \\
6 & $1.5 / 127$ & 30 & $0.25^{\mathrm{b}, \mathrm{c}}$ & $44.25^{\mathrm{c}, \mathrm{d}, \mathrm{e}}$ \\
7 & $1.0 / 120$ & 15 & $0.20^{\mathrm{e}}$ & $54.50^{\mathrm{a}}$ \\
8 & $1.0 / 120$ & 45 & $0.23^{\mathrm{c}, \mathrm{d}}$ & $47.31^{\mathrm{b}, \mathrm{c}, \mathrm{d}}$ \\
9 & $1.0 / 120$ & 30 & $0.24^{\mathrm{b}, \mathrm{c}}$ & $44.84^{\mathrm{c}, \mathrm{d}, \mathrm{e}}$ \\
10 & $1.0 / 120$ & 30 & $0.25^{\mathrm{b}, \mathrm{c}}$ & $44.80^{\mathrm{c}, \mathrm{d}, \mathrm{e}}$ \\
\hline \multicolumn{5}{c}{} \\
\hline
\end{tabular}

Results are the mean of three determinations. Within columns, means with same superscript are not significantly different $(\mathrm{P}>0.05)$.

As can be seen, autoclaving process occasioned a reduction in the content of resistant starch varying from $29.7 \%$ (run 2) to $45.9 \%$ (run 7). Multivariate analysis indicates that binomial pressure/temperature $\left(X_{l}\right)$ and the combined effect of pressure/temperature and autoclaving time $\left(X_{2}\right)$ had a significant effect on the content of resistant starch (Fig. 1b). The response surface for the effect of autoclaving conditions in the content of resistant starch presented an overall curvilinear profile (Fig. 2b). As shown in Fig. 2b, the higher reduction in the resistant starch was found to occur in the higher pressure/temperature and autoclaving time. The minimum 
reduction was obtained in the less drastic autoclaving condition (0.5 $\left.\mathrm{Kgf} \mathrm{cm}^{-2} / 111{ }^{\circ} \mathrm{C} ; 15 \mathrm{~min}\right)$, whereas the maximum reduction in was found in the autoclaving at $1.0 \mathrm{Kgf} \mathrm{cm}{ }^{-2} / 120^{\circ} \mathrm{C}$ for $15 \mathrm{~min}$ (run 7 ).
The regression analysis showed an adequate fit of experimental values to the second-order polynomial model as a function of significant factors. The mathematical model is represented by the equation (8):

$$
\text { Resistant starch }\left(\mathrm{g} \mathrm{g}^{-1} \text { total starch }\right)=0.49-0.37 \mathrm{X}_{1}+0.12 X_{1}^{2}+0.003 X_{1} X_{2} \quad\left(\mathrm{r}^{2}=0.81\right)
$$

The combined effect of the binomial pressure/temperature and autoclaving time probably caused changes in the morphology of the starch granule, increasing the content of molecules susceptible to $\alpha$ amylase and amyloglucosidase action.

The reduction on the content of resistant starch contributed to an improvement on the starch digestibility. As can be observed in Table 3 , the autoclaving process increased the starch in vitro digestibility that presented values varying from $20.34 \%$ (run 1) to $54.50 \%$ (run 7).

The variable pressure/temperature $\left(X_{l}\right)$ and the factor interaction $\left(X_{1} X_{2}\right)$ had a significant effect $(\mathrm{p}<0.05)$ on the starch digestibility, whereas autoclaving time $\left(X_{2}\right)$ did not significantly interfere with this response (Fig. 1c). As observed in the response surface plot, higher pressure/temperature levels resulted in higher starch digestibility, particularly at higher processing time (Fig. 2c). Optimum in vitro starch digestibility was observed in the flour from beans autoclaved at $1.0 \mathrm{Kgf} \mathrm{cm}^{-2} / 120{ }^{\circ} \mathrm{C}$ for $15 \mathrm{~min}$ or $1.5 \mathrm{Kgf} \mathrm{cm} / 127{ }^{\circ} \mathrm{C}$ for $45 \mathrm{~min}$. On these conditions the starch digestibility increased more than 3 fold compared to unprocessed hard-to-cook beans.

The regression analysis showed an adequate fit of the experimental values to the second-order polynomial model as a function of significant factors. The mathematical model is represented by the following equation:

$$
\text { Digestibility }(\%)=84.26 X_{1}-26.60 X_{1}^{2}-0.59 X_{1} X_{2}-12.82 \quad\left(r^{2}=0.82\right)
$$

The digestibility degree of a starch depends on the content of molecules susceptible to hydrolytic activity, as well as on the structural characteristics of the granules. The presence of crystalline structure in the starch granules protects the glucosdic bonds against amylase activity. The autoclaving process probably caused gelatinization, modifying the crystalline structure of the starch and increasing the digestibility of the autoclaved seeds. Exception was observed only for beans autoclaved at 0.5 $\mathrm{Kgf} \mathrm{cm}^{-2} / 111{ }^{\circ} \mathrm{C}$ by $15 \mathrm{~min}$, that presented an increase only $28.4 \%$ in the starch digestibility values.

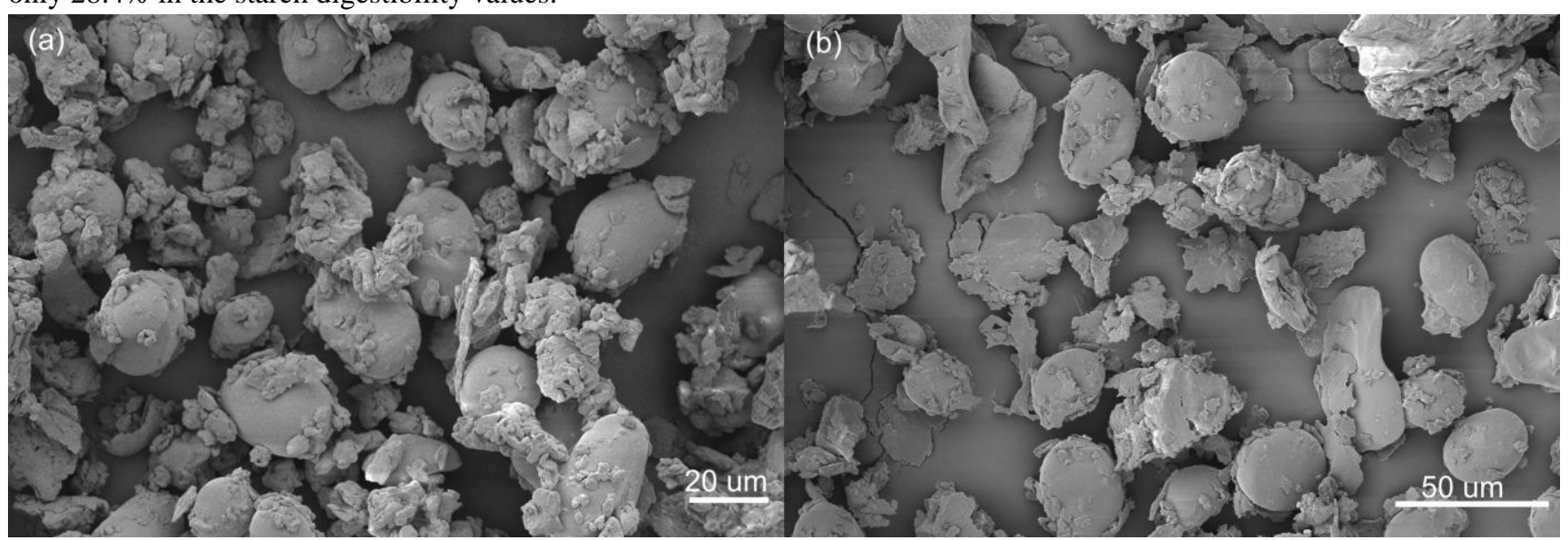

Fig.3: Scanning electron microscopy micrographs of (a) unprocessed hardened bean flour and (b) autoclaved bean flour

Fig.3: Scanning electron microscopy micrographs of (a) unprocessed hardened
$\left(1.5 \mathrm{Kgf} \mathrm{cm}^{-2} / 127^{\circ} \mathrm{C} ; 45 \mathrm{~min}\right)$.
The analysis of SEM micrographs (Fig. 3) of the flour from unprocessed and autoclaved $\left(1.5 \mathrm{Kgf} \mathrm{cm}^{-2} / 127^{\circ} \mathrm{C}\right.$; $45 \mathrm{~min}$ ) hard-to-cook beans showed that in general starch granules were round, elliptical, irregular, kidney and oval shape. They were heterogeneous in size, varying from 13 $\mu \mathrm{m}$ to $26 \mu \mathrm{m}$ (Fig. 3a) in the unprocessed bean flours. The effect of autoclaving may be visualized by the increase in the average size of the granules, which increased from 22 $\mu \mathrm{m}$ to $53 \mu \mathrm{m}$ (Fig. 3b). 
After autoclaving process, several starch granules presented a morphology resembling an amorphous mass of cohesive structure, with loss of granular appearance. This change in appearance from the regular granular shape to an amorphous structure is probably a consequence of the gelatinization occurred during the autoclaving process. The increase in the size of starch granules and the loss of original morphology is a result of swelling and subsequent gelatinization, which makes this substrate more accessible to enzymes, facilitating the starch digestibility.

Moreover, the combined effect of binomial pressure/temperature and autoclaving time caused a partial inactivation of the $\alpha$-amylase inhibitors, contributing to the increase in the starch digestibility. This effect was confirmed by the correlation analysis that showed a negative correlation between the content of $\alpha$ amylase inhibitors with the starch in vitro digestibility $(r=-0.60)$.

\subsection{In vitro Protein Digestibility}

Results from in vitro digestibility of proteins are shown in Table 4. As can be observed the flours from autoclaved bean presented digestibility $41-49 \%$ higher than that of unprocessed beans. The maximum improvement in the digestibility was obtained in the autoclaving conditions of $1.0 \mathrm{Kgf} \mathrm{cm}-2 / 120{ }^{\circ} \mathrm{C}$ and $30 \mathrm{~min}$ (run 9 and run 10). The effect of pressure and temperature during autoclaving leads to a reduction in the content of trypsin inhibitors, improving the protein digestibility what was evidenced in the correlation analysis $(\mathrm{r}=-0.38)$.

In addition, the exposition of a higher number of protein linkages to enzymatic hydrolysis due to protein denaturation during the autoclaving process increases the accessibility to protein peptide bonds and thus improves the digestibility.

Table 4: In vitro protein digestibility and hardness profile of common bean seeds after autoclaving.

\begin{tabular}{ccc}
\hline Run & Protein digestibility (\%) & Hardness (N) \\
\hline 1 & $46.41^{\mathrm{a}}$ & $230.99^{\mathrm{b}}$ \\
2 & $45.77^{\mathrm{a}}$ & $184.14^{\mathrm{d}}$ \\
3 & $45.93^{\mathrm{a}}$ & $210.56^{\mathrm{b}, \mathrm{c}}$ \\
4 & $45.14^{\mathrm{a}}$ & $135.84^{\mathrm{e}}$ \\
5 & $46.33^{\mathrm{a}}$ & $230.19^{\mathrm{b}}$ \\
6 & $46.72^{\mathrm{a}}$ & $199.16^{\mathrm{c}, \mathrm{d}}$ \\
7 & $45.93^{\mathrm{a}}$ & $251.72^{\mathrm{a}}$ \\
8 & $46.25^{\mathrm{a}}$ & $195.43^{\mathrm{c}, \mathrm{d}}$ \\
9 & $47.52^{\mathrm{a}}$ & $257.78^{\mathrm{a}}$ \\
10 & $47.51^{\mathrm{a}}$ & $257.47^{\mathrm{a}}$ \\
\hline Unprocessed hardened beans & $31.96^{\mathrm{b}}$ & $268.07^{\mathrm{a}}$ \\
\hline
\end{tabular}

Results of digestibility are the mean of three determinations. Results of hardness are the mean of fifty determinations. Within columns, means with same superscript are not significantly different $(\mathrm{P}>0.05)$.

\subsection{Texture analysis}

Hardness is a textural problem that occurs when beans fail to soften sufficiently during the normal cooking process. The harder texture presented by hard-to-cook beans is a result of the reduction in the hydration (imbibition) and swelling of the seeds, which in turn, reduce their cookability and consumer acceptance (Nasar-Abbas et al., 2008). This reduction in the water uptake and softening of the cotyledon tissue leads to beans with inferior texture and mouthfeel. The hardness is probably caused by a poor cell separation, improper starch gelatinization and changes in the protein denaturation temperature (Yousif, Deeth, Caffin, \& Lisle, 2002).

As observed in the Table 4, the unprocessed seeds had the highest values of hardness. However, the autoclaved seeds presented a reduction varying from $3.9 \%$ (run 9) to $49.3 \%$ (run 4), depending on the autoclaving parameters.

The results from multivariate analysis showed that all factors negatively affected the hardness $(p<0.05)$, and the linear term of autoclaving time showed the most pronounced effect on this response (Fig. 1d). As can be seen in Fig. 2d, the hardness values decreased with improvement of the pressure/temperature and autoclaving time. The maximum reduction in the hardness was observed in the seeds autoclaved at $1.5 \mathrm{Kgf} \mathrm{cm} / 127{ }^{\circ} \mathrm{C}$ for $45 \mathrm{~min}$ (Table 4). The regression analysis for hardness showed an adequate fit of the experimental values to the second-order polynomial model as a function of significant factors. The mathematical model can be represented by the following equation $\left(r^{2}=0.91\right)$ :

$$
\text { Hardness }(N)=56.13+293.59 \mathrm{X}_{1}-149.49 X_{1}^{2}+6.54 X_{2}-0.13 X_{2}^{2}-0.93 X_{1} X_{2}
$$


The combined effect of pressure and temperature during the autoclaving probably changed the cell adherence increasing the cell separation, which leads to seeds with lower hardness. The reduction on the hardness will contribute to improvement of the texture and palatability of the hard-to-cook beans.

\section{CONCLUSIONS}

The results obtained in this study evidenced that autoclaving process improves the nutritional characteristics of hard-to-cook beans, while preserves its functional properties. The reduced activity of the enzyme inhibitors and amount of resistant starch as consequence of autoclaving, leads to an improvement on the nutrient bioavailability. Additionally, the decrease in the hardness make the autoclaved hard-to-cook beans products with better texture and palatability, compared to the unprocessed hard-to-cook seeds. These results evidenced that autoclaving may be an interesting alternative to improve the nutritional and functional quality of the hardto-cook beans allowing its introduction in human consume as whole grain or component in food preparations.

\section{ACKNOWLEDGEMENTS}

This work was supported by CNPQ (Process numbers: 479649/2010-3 and 426284/2016-0) and CAPES (Finance code 001). We are very thankful to Empresa Brasileira de Pesquisa Agropecuária/ (EMBRAPA), for supplying the beans.

\section{REFERENCES}

[1] Batista, K A, Prudêncio, S H, \& Fernandes, K F. (2010a). Changes in the biochemical and functional properties of the extruded hard-to-cook cowpea (Vigna unguiculata L. Walp). International Journal of Food Science and Technology, 45, 794-799.

[2] Batista, K A, Prudêncio, S H, \& Fernandes, K F. (2010b). Changes in the functional properties and antinutritional factors of extruded hard-to-cook common beans Journal of Food Science, 75, 286-290.

[3] Batista, K A, Prudêncio, S H, \& Fernandes, K F. (2011). Wheat bread enrichment with hard-to-cook bean extruded flours: nutritional and acceptance evaluation. Journal of Food Science, 76, S108-S113.

[4] Deshpande, S S, Sathe, S K, Salunkhe, D K, \& Comforth, D P. (1982). Effects of dehulling on phytic acid, polyphenols, and enzyme inhibitors of dry beans (Phaseolus vulgaris L.). Journal of Food Science, 47, 1846-1850.

[5] Goni, I, Garia-Alinos, A, Manas, E, \& Saura-Calixto, F. (1997). A starch hydrolysis procedure to estimate glycemic index. Nutrition Research, 17, 427-437.

[6] Guerrero-Beltrán, J A, Estrada-Girón, Y, Swanson, B G, \& Barbosa-Cánovas, G V. (2009). Pressure and temperature combination for inactivation of soymilk trypsin inhibitors. Food Chemistry, 116, 676-679.

[7] Kakade, M L, Rackis, J L, McGhee, J E, \& Puski, G. (1974). Determination of trypsin inhibitor activity of soy bean products: a collaborative analysis of an improved procedure. Cereal Chemistry, 51, 376-382.

[8] Khattab, R Y, \& Arntfield, S D. (2009). Nutritional quality of legume seeds as affected by some physical treatments: 2 . Antinutritional factors. LWT-Food Science and Technology, 42, 1113-1118.

[9] Lopes, L C M, Batista, K A, Fernandes, K F, \& Santiago, R A C. (2012). Functional, biochemical and pasting properties of extruded bean (Phaseolus vulgaris) cotyledons. International Journal of Food Science and Technology, 47, 1859-1865.

[10] Nasar-Abbas, S M, Plummer, J A, Siddique, K H M, White, P, Harris, D, \& Dods, K. (2008). Cooking quality of faba bean after storage at high temperature and the role of lignins and other phenolics in bean hardening. LWT - Food Science and Technology, 41, 1260-1267.

[11] Okezie, B O, \& Bello, A B. (1988). Physicochemical and functional properties of winged bean flour and isolate compared with soy isolate. Journal of Food Science, 53, 450-454.

[12] Rehman, Z, \& Shah, W H. (2005). Thermal heat processing effects on antinutrients, protein and starch digestibility of food legumes. Food Chemistry, 91, 327-331.

[13] Ribeiro, H J S S, Prudencio-Ribeiro, S H, \& Miyagui, D T. (2005). Propriedades físicas e químicas de feijão comum preto, cultivar Iapar 44, após envelhecimento acelerado. Ciência e Tecnologia de Alimentos, 25, 165-169.

[14] Ruiz-Ruiz, J, Martinez-Ayala, A, Drago, S, \& González, R. (2008). Extrusion of a hard-to-cook bean (Phaseolus vulgaris, L.) and quality protein maize (Zea mays L.) flour blend. LWT - Food Science and Technology, 41, 17991807.

[15] Shiga, T M, Lajolo, F M, \& Filisetti, T M C C. (2004). Changes in the cell wall polysaccharides during storage and hardening of beans. Food Chemistry, 84, 53-64.

[16] Shimelis, E A, \& Rakshit, S K. (2007). Effect of processing on antinutrients and in vitro protein digestibility of kidney bean (Phaseolus vulgaris L.) varieties frown in East Africa. Food Chemistry, 103, 161-172.

[17] Svensson, B, Fukuda, K, Nielsen, P K, \& Bonsager, B C. (2004). Proteinaceous $\alpha$-amylase inhibitors. Biochimica et Biophysica Acta, 1696, 145-156.

[18] Toledo, N M V, Rocha, L C, Silva, A G, \& Brazaca, S G C. (2013). Interaction and digestibility of phaseolin/polyphenol in the common bean. Food Chemistry, 138, 776-780.

[19] Yousif, A M, Deeth, H C, Caffin, N A, \& Lisle, A T. (2002). Effect of storage time and conditions on the hardness and cooking quality of adzuki (Vigna angularis). LWT - Food Science and Technology, 35, 338-343. 